Predpriimchivost kak integralnaya cherta lichnosti cheloveka [Entrepreneurship as an integral trait of personality]. Alma mater. Bulletin of higher education. No. 3. [in Russian].

9. Selivanova, Ju. V. \& Zajcev, D. V. (2014). Socialnaja integracija lichnosti: sociologicheskij podhod $\mathrm{k}$ analizu ponjatija [Social integration of personality: a sociological approach to the analysis of the concept]. Proceedings of Saratov University. Series "Sociology. Political science". Vol. 14, vol. 2. pp. 41-44. [in Russian].

10. Strelnikov, M.(2015). Struktura pidpryiemnytskoi kompetentnosti mahistriv spetsialnosti "Biznesadministruvannia" [Structure of Entrepreneurial Competence of Masters of the Specialty "Business Administration"] KSPU Scientific Notes. (Series.: Pedagogical Sciences).Vol. 141. Vol.2.pp. 148-151. [in Ukrainian].

11. Shadrikov, V. D. (1996). Psihologija dejatelnosti $i$ sposobnosti cheloveka: uchebnoe posobie [Psychology of human activity and ability: a training manual]. Moscov, 320 p. [in Russian].

12. Council recommendation of 22 May 2018 on key competences for lifelong learning (Text with EEA relevance) (2018/C 189/01). [in English].

Стаття надійшла до редакції 19.06.2019

УДК: 378.147 .032

DOI:

Дмитро Кузьменко, аспірант кафедри соичільної роботи Національний університет “Чернігівський колегіум” імені Т.Г. Шевченка

\title{
САМОРЕГУЛЯЦІЯ МАЙБУТНІХ ЮРИСТІВ В ОСВІТНЬОМУ ПРОЦЕСІ ЗАКЛАДІВ ВИЩОЇ ОСВІТИ
}

У статті здійснено аналіз саморегуляиії в процесі підготовки бакалаврів майбутніх юристів. Показано, що теоретичні узагальнення з иієї проблеми спонукають ретельніше вводити в начіональну систему професійної підготовки майбутніх юристів саморегуляцію в освітній прочес. 3'ясування особливостей цієї проблеми дає підтрунтя для зіставлення та виявлення аспектів саморегуляиії (особистісної та професійної). Зазначено, що саморегуляція як педагогічна проблема є необхідною для професійного розвитку майбутніх юристів.

Ключові слова: саморегулячія; студенти; саморегулячія у освітньому процесі; майбутні юристи; заклади вищої освіти.

Jim. 15.

Dmytro Kuzmenko, Postgraduate Student of the Social Work Department Taras Shevchenko National University "Chernihiv Collehium"

\section{SELF-REGULATION OF FUTURE LAWYERS IN THE EDUCATIONAL PROCESS OF HIGHER EDUCATION INSTITUTIONS}

The article analyzes the self-regulation in the process of preparation of bachelors of future lawyers. It is shown that theoretical generalizations on this problem lead to a more thorough introduction of self-regulation in the educational process into the national system of professional training of future lawyers. Finding out the peculiarities of this problem provides a basis for comparing and identifying aspects of self-regulation (personal and professional). It is noted that self-regulation as a pedagogical problem is necessary for the professional development offuture lawyers.

The task of institutions of higher education is to expand the property of self-regulation into the intellectual sphere, that is, to develop skills of self-regulation of cognitive activity at the conditional and reflex level of students.

Educational activities for undergraduate students should be a continuation of the natural processes of selfregulation. An external influence for future lawyers is an educational task that has a difficulty. Future lawyers must have the knowledge, skills and abilities of the future; have a high level of motivation, and the need to formulate readiness for self-regulation both personal and professional. We have determined that self-regulation is a person's ability to manage his state of health, emotions, mental state of his organism, actions, behavior and professional activity. The specificity of the structure of the educational activities of future lawyers evolves into deliberately regulated educational activity, based on more complex logical operations. The development of educational material, aimed at finding a generalized equivalent, and assimilation constitute the content of logical memorization, and ways of finding this equivalent - techniques of logical memorization. It is revealed that undergraduate students are not necessarily to be aware of all laws and legislative acts of Ukraine and international law, but clearly know where to find the right material quickly. 
Prospects for further scientific research we consider the professional self-regulation of future lawyers studying in the magistracy of institutions of higher education.

Keywords: self-regulation; students; self-regulation in the educational process; future lawyers; institutions of higher education.

П остановка проблеми. Саморегуляція $\epsilon$ багатофакторним феноменом, який сприяе створенню соціально-педагогічного простору для особистості. Визначення саморегуляції як психосоціального утворення, яке формується на основі виконання освітніх операцій у певній послідовності створюють динамічний стереотип у розумовій праці майбутнього юриста.

Для нашої статті важливим $є$ педагогічне тлумачення саморегуляції як сформованої сукупності навичок рефлексивного сприйняття змісту, завдання і оволодіння засобами виконання таким чином, щоб будь-яка зміна умов завдання, зустріч $з$ утрудненнями спричиняе таку дію мислення, яка призводить до самостійного розв'язку завдання чи проблеми, що забезпечує саморегуляцію майбутнього юриста.

Завдання закладів вищої освіти - розширити властивість саморегуляції на інтелектуальну сферу, тобто сформувати навички саморегуляції пізнавальної діяльності на умовно-рефлекторному рівні студентів.

Освітня діяльність для студентів бакалаврату повинна стати продовженням природних процесів саморегуляції. Зовнішнім впливом для майбутніх юристів є освітне завдання, яке містить утруднення. Викладачам ЗВО необхідно сформувати такі механізми, які б спонукали студентів до подолання утруднення і успішного виконання освітніх завдань.

Аналіз наукових досліджень. Дослідження поняття саморегуляції здійснювали як зарубіжні, так й вітчизняні науковці. М.М. Амосов, вважав, що людина - це найскладніша, саморегульована, самонавчаюча система [1]. 3 біологічної сторони проблеми Павлов I. стверджував, що людина $\epsilon$ системою у найвищий мірі саморегульованою, здатною саму себе підтримувати, відновлювати, виправляти, удосконалювати [14].

У 1980 році на XXII Міжнародному конгресі психологів у Лейпцигу О. Конопкін сформулював основні принципи саморегуляції діяльності людини: системність, активність, усвідомленість $[9,20]$.

На думку професора М.В. Гриньової $[5,3]$ "саморегуляція - це вміння людини бачити кінцеву мету діяльності, самостійно знаходити оптимальні шляхи їі досягнення і добиватися здійснення". На необхідність вивчення саморегуляції як компонента загальної обдарованості вказували науковці Б. Ананьев, Н. Лейтес. Вони довели, що першооснову потенцій людини як суб'єкта діяльності слід шукати у нерозривному взаємозв'язку розумової активності і саморегуляції $[2 ; 10]$. Дослідник М. Савчин констатував, що одним із результатів вдосконалення професійної діяльності $€$ формування саморегульованої функції діяльності $[6,33]$. Проблема саморегуляції і самоконтролю в рамках теорії освітньої діяльності розглядається у роботах А.Маркової. Науковець вважає “свідому постановку суб'єктом цілей на основі наступних видів діяльності та підлягання їм способів своєї навчальної діяльності" [12, 52].

Мета статті. Дослідження основних аспектів саморегуляції як вищої ланки освітньої діяльності в закладах вищої освіти.

Виклад основного матеріалу. В українській науковій літературі визначено, що саморегуляція - феномен стабільності природи і людини. Термін "саморегуляція" означає "здатність біологічної системи по відновленню стабільного рівня тих чи інших функцій після їхньої зміни". При саморегуляції керуючі фактори не діють на керовану систему зовні, а виникають у ній самій самочинно. Термін "регулювання" походить від латинського regula - норма, правило, стабілізація. У ВРЕ “саморегулювання” (самовирівнювання) - здатність машин відновлювати без участі регулятора стійкий режим роботи після раптового порушення його з боку зовнішніх або внутрішніх факторів" $[4,127]$.

Саморегуляція виховує відповідальне ставлення до юридичної діяльності студентів бакалаврату. Суть саморегуляції полягає у спроможності студентів долати прагнення до задоволення миттєвих потреб в інтересах об'єктивно і суб'єктивно більш цінних, але віддалених у часі i просторі цілей. Саморегулююча система реалізує "витривалість показників її роботи”, “шляхом внутрішніх змін”, породжуваних самою системою відповідно до законів її організації. Саморегуляція у освітньому процесі - це оволодіння засобами виконання освітніх операцій так, щоб будь-яка зміна умов завдання, зустріч з різними утрудненнями спричиняли таку дію мислення, яка призводить до самостійного розв'язання проблеми особливо в процесі підготовки майбутніх юристів. Саморегуляція формується шляхом здійснення освітньої діяльності. Це пов'язано з появою у свідомості студентів новоутворень, основою яких $є$ сприйняття освітніх завдань і рефлексія освітніх дій $[5,6]$. 


\section{САМОРЕГУЛЯЩІЯ МАЙБУТНІХ ЮРИСТІВ В ОСВІТНЬОМУ ПРОЩЕСІЗАКЛАДІВ ВИЩОЇ ОСВІТИ}

У роботі І. Павлова - “Рефлекс цілі”, який, як вказував вчений на III з'їзді з експериментальної фізіології, вона має "велике життєве значення, $є$ основною формою життєвої енергії кожного з нас". Відмітимо той факт, що І. Павлов одним з перших увів у науковий обіг термін “самоуправління” і ще в 1916 році підкреслював необхідність розгорнути дослідження, які будуть сприяти розумінню нас самих і розвинутих у нас здібностей до особистого самоуправління. Йому належить учення про другу сигнальну систему, якій учений відводив роль вищого регулятора людської поведінки, називаючи слово сигналом сигналів [14, 310].

Науковець М. Вінер констатує, що саморегуляція притаманна всім живим системам, вона стала основою створення передової техніки. Вивчення механізмів регуляції в біологічних системах дає можливість відібрати сукупність педагогічних засобів, які дозволяють регулювати мислення і формувати саморегуляцію навчальної діяльності [3, 82].

Маємо зазначити, що діяльність є основою формування саморегуляції.

Діяльність виховує людину і формує їі саморегуляцію. Як стверджує науковець О. Леонтьєв, “діяльність - це процес активності суб'єкта, який відповідає мотиву, дія, що відповідає тій чи іншій іiі цілі, та операція, яка відповідає умовам, у яких вона здійснюється" [11, 112]. Діяльність студентів, іiі спрямування, розвиток, організація є тією ланкою, яка дозволяє створити умови розвитку здібностей майбутніх юристів, формування готовності і здатності до самоосвіти.

Діяльність суб'єкта завжди пов'язана 3 потребою і породжується зіткненням потреби 3 опором здійсненню дії людини, до якого додається соціальний опір у вигляді норм, правил, заборон. Тому людська діяльність має предметний і соціально-історичний характер. За В. Давидовим, вихідною формою всіх видів діяльності людини $є$ суспільно-історична практика людського роду, тобто цілеспрямована, суттєво-предметна, перетворююча, колективна трудова діяльність людей. Діяльність - це взаємодія з об'єктивним світом суспільної людини, вона є єдністю матеріально-перетворюючого та духовного начал. Чим вищий рівень діяльності, тим сильніша потреба в її духовності. При цьому є способом перетворення світу 3 метою задоволення життєвих потреб людини [7, 22].

Основний вид людської діяльності-праця. Всі інші види діяльності є похідними від неї. Праця людини носить організований, свідомий i суспільний характер. Усі предмети, необхідні для цивілізованого життя, створюються розумом і руками людини. Все, що необхідно для життя людини, вона одержує від суспільства в обмін на свою працю [6, 34].

Психолог С.Л. Рубинштейн вважав, що людина не тільки змінює форму того, що дано природою, вона здійснює в той же час і свою свідому мету, яка як закон визначає спосіб і характер іії дій і якій вона повинна підпорядкувати свою волю $[15,50]$. Це твердження маємо віднести безпосередньо до процесу особистісної саморегуляції.

Освітня діяльність має певну структуру, яка включає: завдання діяльності, об'єкти, на які діяльність спрямована; процес, який складається 3 дій або операцій з об’єктами; засоби, необхідні для побудови об'єкта; продукт діяльності. Діяльність $є$ процес, який спричиняє зміни в часі певної сукупності об'єктів. У ході виконання освітньої діяльності змінюється не об'єкт діяльності, а ії̈ суб'єкт, тобто студент, що пов'язано 3 появою в його свідомості новоутворень, основою яких, є засвоєння освітнього матеріалу.

Діяльність можна вважати освітньою тільки в тому випадку, коли зміна в суб’єкті, що відбувається, відповідає їі цілям. При виконані освітньої діяльності досвід, який набувається, є в готовому вигляді, і суб'єкт пізнання - студент (в нашому дослідженні студент бакалаврату) повинен виконувати певні дії для його сприйняття і засвоєння.

Освітня діяльність складається 3 двох підсистем: діяльності учіння та діяльності навчання. Діяльність учіння здійснюється студентом і $є$ пізнавальною діяльністю, бажаним продуктом якої $є$ необхідна трансформація вихідного досвіду студентів - майбутніх юристів. До діяльності учіння належать усі акти, які забезпечують засвоєння освітнього матеріалу. Суб'єктом учіння є студент. Предметом діяльності учіння $є$ освітній процес, направлений на одержання кінцевого продукту. Продуктом освітньої діяльності є знання, уміння і навички. Для нашого дослідження найбільш вагомими знання. Це набуття студентом досвіду, одержаного людством. Знання - це образи предметів, явищ матеріального світу та їх взаємозв'язків, образи дій людини 3 цими предметами. Знання мають складну структуру, яка містить три рівні. Першим є рівень відображення дійсності, який дає інформацію про неї. Другим є рівень мислительної реконструкції відображувального об'єкта і створення його образу. Третій - це рівень схеми, практичної дії, він представляє матеріалізацію створеного образу в діяльності. Така структура знання стала основою для опрацювання механізму формування саморегуляції освітньої діяльності [4, 126]. 
Поряд із вагомістю впливу знань студентів бакалаврату на операції мислення варто підкреслити й значну роль умінь студентів.

У Національній доктрині розвитку освіти України в XXI ст. зазначено, що модернізація системи освіти спрямована на забезпечення іï якості засобами збереження наступності навчання на різних ступенях освіти, особистісною орієнтацією. Це призводить до вирішення таких кардинальних проблем, як забезпечення міжпредметних зв'язків між окремими ланками шкільного навчання, чіткої системи безперервності навчання, вдосконалення структури освітніх [13].

Визначимо структурні компоненти саморегуляції діяльності в освітньому процесі вишів. Для цього розглянемо узагальнення вченого О. Конопкіна. Він висунув тезу про те, що для діяльності людини (включаючи iï найбільш елементарні форми) усвідомлення регулювання є вищим рівнем саморегуляції $[8,92]$.

Маємо констатувати, що мета діяльності $\epsilon$ важливою ланкою процесу саморегуляції, визначає напрям діяльності людини i постійно усвідомлюється нею. Суб'єктивна модель значущих умов визначає умови, в яких відбувається досягнення мета діяльності. Програма дій являє собою оптимальний спосіб досягнення мети у заданих умовах. Оцінюючі дії завершують процес регуляції, перетворюючи його у замкнуту систему, там самим організовуючи та скеровуючи довільну діяльність людини. Тому можемо стверджувати, шо функціональна модель процесу саморегуляції знеособлює психологічний зміст (емоції, волю, мислення).

Отже, змістовна сторона процесу саморегуляції набуває головної якості, а саме - визначеності. Усвідомлюючи завдання, студенти стають суб'єктами власної діяльності, самостійно аналізують умови завдання, шукають спосіб перетворення вихідної ситуації, оцінюють результат. Зазначимо, що майбутніми юристами в нашому дослідженні вважаємо студентів бакалаврату Національного університету “Чернігівський колегіум” імені Т.Г. Шевченка.

Сьогодні особливий інтерес науковців зосереджено на проблемі формування професійної компетентності фахівців різних професій, у тому числі й майбутніх юристів. Це зумовлено значною інноваційною динамікою сучасного ринку праці, який висуває нові вимоги до випускників закладів вищої освіти.

Особливу увагу варто звернути на роль емоційного інтелекту у формуванні професійної компетентності майбутніх фахівців юридичної сфери. Те, як майбутні юристи поводять себе у цьому процесі, значною мірою визначається рівнем їхнього емоційного інтелекту.

Висновки. Підсумовуючи, маємо зазначити, що професійна підготовка майбутніх юристів в сучасних умовах передбачає не тільки формування фахівця, здатного до виконання певної соціальної ролі, але й його готовність до діяльності в юридичній сфері. Студенти бакалаврату мають володіти достатніми знаннями, уміннями й навичками, мати високий рівень мотивації, потреби у формуванні готовності до саморегуляції як особистісної так й професійної. Нами визначено, що саморегуляція - це уміння особистості керувати станом свого здоров'я, емоціями, психічним станом свого організму, діями, вчинками, поведінкою та професійною діяльністю. Специфіка структури освітньої діяльності майбутніх юристів переростає в свідомо регульовану освітню діяльність, що спирається на більш складніші логічні операції. Опрацювання освітнього матеріалу, спрямоване на пошук узагальненого еквівалента, і засвоєння становлять зміст логічного запам'ятовування, а способи знаходження цього еквівалента прийоми логічного запам'ятовування. Тобто студенти бакалаврату не обов'язково на пам'ять мають знати всі закони та нормативно-правові акти України й міжнародного права, проте чітко знати де швидко знайти потрібний матеріал.

Перспективами подальших наукових розвідок вважаємо професійну саморегуляцію майбутніх юристів, які навчаються в магістратурі закладів вищої освіти.

\section{ЛІТЕРАТУРА}

1. Амосов Н. М. Регуляция жизненных функций и кибернетика. Київ, 1984. 116 с.

2. Ананьев В. Г. Комплексное исследование человека и психическая диагностика. Вопросы психологии. 1968. № 6.

3. Винер Н. Творец и робот. Обсуждения некоторых проблем, в которых кибернетика сталкивается с религией. Москва, 1966. 103 с.

4. Гриньова М. В. Значення саморегуляції у цілісному навчально-виховному процесі. Єдність педагогіки і психології у цілісному навчальновиховному процесі. Мат. Всеукр. наук.-практ. конф. Полтава, 1995. С. 126-128.

5. Гриньова М. В. Саморегуляція: навчальнометодичний посібник. Полтава: ACML-2008. 268 с.

6. Гриньова М. В., Палажченко Е. Ф. До питання про формування саморегуляції навчальних дій. Наукові записки психолого-педагогічного факультету. Ч. ІІ. Полтава, 1997. С. 30-35. 
7. Давыдов В. В. О психическом анализе содержания действий. Тезиси докладов на II съезде Общества психологов. Киев, 1961. С. 21-23.

8. Конопкин О. А., Жуйков Ю. С. Психологические механизмы регуляции деятельности. Под. ред. Ошанина Д. А., Конопкина О. А. Москва, 1973. C. $87-128$.

9. Конопкин О. А., Степанский В. И. Саморегуляция деятельности в условиях временной неопределенности исполнительских сигналов. Вопросы психологии. 1972. № 4. С. 15-28.

10. Лейтес Н. С. Умственные способности и возраст. Москва, 1971. 278 с.

11. Леонтьев А. Н. Потребности, мотивы и эмоции. Москва, 1971. $186 \mathrm{c.}$

12. Маркова А. К., Орлов А. Б., Фридман Л. М. Мотивация учения и ее воспитание у школьников. НШС общей и педагогической психологии АПИ СССР. Москва, 1983. 64 с.

13. Національна доктрина розвитку освіти України у XXI столітті. Київ, 2001. 16 с.

14. Павлов И. П. Сообщение на III съезде по экспериментальной физиологии в Петрограде 2 января 1916 г. Полн. собр. соч. Москва, 1951. Т. 3. С. $306-313$.

15. Рубинштейн С. Л. Основы общей психологии. В 2-х тт. Т. II. Москва. 1989. 328 с.

\section{REFERENCES}

1. Amosov, N. M. (1984). Regulyatsiya zhiznennykh funktsiy i kibernetika [Regulation of vital functions and cybernetics]. Kyiv, p. 116. [in Ukrainian].

2. Ananev, V. G. (1968). Kompleksnoe issledovanie cheloveka i psikhicheskaya diagnostika [Complex research of the person and mental diagnostics]. The issues of Psychology.No. 6. [in Russian].

3. Viner, N. (1966). Tvorets i robot. Obsuzhdeniya nekotorykh problem, v kotorykh kibernetika stalkivaetsya s religiey [Creator and robot. Discussion of some issues in which cybernetics faces religion]. Moscov, p. 103. [in Russian].

4. Ghrynjova, M. V. (1995). Znachennja samoreghuljaciji u cilisnomu navchaljno-vykhovnomu procesi [The meaning of self-regulation in a holistic educational process]. Jednistj pedaghoghiky $i$ psykhologhiji u cilisnomu navchaljnovykhovnomu procesi. Mat. Vseukr. nauk.-prakt. konf. - The unity of pedagogy and psychology in a holistic educational process. Proceedings of the All-
Ukrainian. Research and Practice Conf. (pp. 126128). Poltava. [in Ukrainian].

5. Ghrynjova, M. V. (2008). Samoreghuljacija: navchaljno-metodychnyj posibnyk [Self-regulation]. Poltava, p. 268. [in Ukrainian].

6. Ghrynjova, M. V. \& Palazhchenko, E. F. (1997). Do pytannja pro formuvannja samoreghuljaciji navchaljnykh dij [On the question of formation of selfregulation of educational actions]. Scientific notes of the Faculty of Psychology and Education. Part. II. Poltava, pp. 30-35. [in Ukrainian].

7. Davydov, V. V. (1961). O psikhicheskom analize soderzhaniya deystviy [About mental analysis of the content of action]. Abstracts of the reports of the II Congress of the Society of Psychologists. Kyiv, pp. 21-23. [in Ukrainian].

8. Konopkin, O. A. \& Zhuykov, Yu. S. (1973). Psikhologicheskie mekhanizmy regulyatsii deyatelnosti [Psychological mechanisms of regulation of activity]. (Ed.). Oshanina D. A., Konopkina O. A. Moscov, pp. 87-12. [in Russian].

9. Konopkin, O. A. \& Stepanskiy, V. I. (1972). Samoregulyatsiya deyatelnosti v usloviyakh vremennoy neopredelennosti ispolnitelskikh signalov [Self-regulation of activity under the conditions of time uncertainty of the performance signals]. The issues of Psychology. No. 4, pp. 15-28. [in Russian].

10. Leytes, N. S. (1971). Umstvennye sposobnosti $i$ vozrast [Mental abilities and age]. Moscov, p. 278. [in Russian].

11. Leontev, A. N. (1971). Potrebnosti, motivy $i$ emotsii [Needs, motives and emotions]. Moscov, p. 186. [in Russian].

12. Markova, A. K., Orlov, A. B. \& Fridman, L. M. (1983). Motivatsiya ucheniya i ee vospitanie u shkolnikov [The motivation of learning and its education in schoolchildren]. NShS obshchey $i$ pedagogicheskoy psikhologii API SSSR. Moscov, p. 64. [in Russian].

13. Nacionaljna doktryna rozvytku osvity Ukrajiny u XXI stolitti (2001). [National Doctrine of Ukrainian Education Development in the XXI Century]. Kyiv, p. 16. [in Ukrainian].

14. Pavlov, I. P. (1951). Soobshchenie na III sezde po eksperimentalnoy fiziologii v Petrograde 2 yanvarya $1916 \mathrm{~g}$. [Report at the III Congress on Experimental Physiology in Petrograd, January 2, 1916]. Moscov. Vol. 3, pp. 306-313. [in Russian].

15. Rubynshtejn, S. L. (1989). Osnovy obshchey psikhologii [Basics of General Psychology]. Vol. 2. Moscov, 328 p. [in Russian].

Стаття надійшла до редакції 24.06.2019

\section{G5808

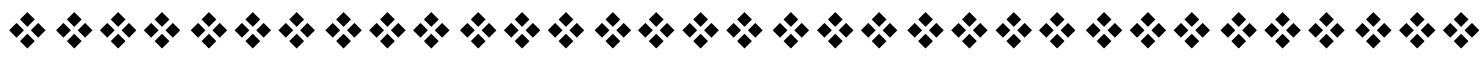

